\title{
Response of Cenozoic turbidite system to tectonic activity and sea- level change off the Zambezi Delta
}

\author{
Jude A. Castelino ${ }^{1}$ - Christian Reichert $^{2} \cdot$ Wilfried Jokat $^{1}$
}

Received: 30 September 2016 / Accepted: 16 February 2017 / Published online: 13 March 2017

(C) European Union 2017

\begin{abstract}
Submarine fans and turbidite systems are important and sensitive features located offshore from river deltas that archive tectonic events, regional climate, sea level variations and erosional process. Very little is known about the sedimentary structure of the $1800 \mathrm{~km}$ long and $400 \mathrm{~km}$ wide Mozambique Fan, which is fed by the Zambezi and spreads out into the Mozambique Channel. New multichannel seismic profiles in the Mozambique Basin reveal multiple feeder systems of the upper fan that have been active concurrently or consecutively since Late Cretaceous. We identify two buried, ancient turbidite systems off Mozambique in addition to the previously known Zambezi-Channel system and another hypothesized active system. The oldest part of the upper fan, located north of the present-day mouth of the Zambezi, was active from Late Cretaceous to Eocene times. Regional uplift caused an increased sediment flux that continued until Eocene times, allowing the fan to migrate southwards under the influence of bottom currents. Following the mid-Oligocene marine regression, the Beira High Channel-levee complex fed the Mozambique Fan from the southwest until Miocene times, reworking sediments from the shelf and continental slope into the distal abyssal fan. Since the Miocene, sediments have bypassed the shelf and upper fan region through the Zambezi Valley system directly into the Zambezi Channel. The morphology of the turbidite system off Mozambique
\end{abstract}

Jude A. Castelino

Jude.Castelino@awi.de

1 Alfred Wegener Institute, Hemholtz Centre for Polar und Marine Research (AWI), Am Alten Hafen 26, 27568 Bremerhaven, Germany

2 Bundesanstalt für Geowissenschaften und Rohstoffe (BGR), Stilleweg 2, 30655 Hanover, Germany is strongly linked to onshore tectonic events and the variations in sea level and sediment flux.

Keywords Mozambique Fan - Turbidite systems · Late Cretaceous bottom current - Beira High Channel-levee system · African Uplift · Zambezi River

\section{Introduction}

River-fed turbidite systems (e.g., Amazon, Mississippi, Bengal, Indus, Congo, etc.) build fans, channels and channel related features that can extend for over $1000 \mathrm{~km}$ and are more than $100 \mathrm{~km}$ wide (Mutti and Normark 1991; Weimer and Link 1991). They not only host major oil plays offshore but are also excellent archives to study past climate variations. It is well established that turbidite systems and submarine fans are the results of a complex interplay between numerous environmental parameters, amongst which tectonics, sea-level and sediment supply dominate (Stow et al. 1985). In general, this interplay can be interpreted from geophysical and sedimentological datasets, where these are available, allowing fans to be ultimately linked to a handful of controlling parameters. The formation and growth of the largest submarine fan, the Bengal Fan, trace their origin to the Himalayan orogeny and the monsoon climate that controls sediment supply in the Indian subcontinent (Curray et al. 2003; France-Lanord et al. 2015; Krishna et al. 2016). The morphology and growth of the Amazon Fan, in contrast, are linked to the intensification of weathering and erosion of the Andes during their Late Miocene uplift at a time of rapid sea level variations during glacial and interglacial cycles (Figueiredo et al. 2009; Flood et al. 1991; Gorini et al. 2014; Milliman et al. 1975). 
In contrast, most recent studies of the Mozambique fan off SE Africa have been driven by the needs of the hydrocarbon industry in the wake of significant gas discoveries (INP 2014). In spite of its globally significant volume (Table 1), the relationships between the history and development of the Mozambique Fan (Fig. 1) and its African source regions therefore remain sparsely studied. In particular, the fan offers the possibility to understand the contentious Cenozoic uplift history of southern Africa (Brown et al. 2014; Daszinnies et al. 2009; Emmel et al. 2011; Partridge and Maud 1987; Roberts and White 2010). The aim of this study is to fill this gap in knowledge via analysis of the fan's internal seismic stratigraphy in a new network of multi-channel seismic reflection (MCS) data, tied to stratigraphic information available from hydrocarbon industry studies in the Zambezi Delta Depression (ZDD) (Fig. 1) (Coffin 1992; De Buyl and Flores 1986; Mahanjane et al. 2014; Nairn et al. 1991; Salazar et al. 2013; Salman and Abdula 1995).

\section{Geological setting and previous work}

The Mozambique Fan occupies the Mozambique Channel, a north-south trending ocean basin that formed during Gondwana breakup in Jurassic and early Cretaceous times. The Mozambican margin bounds the upper fan deposits to the north and west, and the Madagascar margin and Davie Ridge bound them to the east, in an almost triangular basin and that opens southwards into the Southwest Indian Ocean (Fig. 1). The Zambezi River is one of the primary sources for sediment supply to the upper fan with as much as 60 Mio tonnes being drained annually into the basin (Kolla et al. 1980b; Van der Lubbe et al. 2014; Walford et al. 2005). The thickest (up to $12 \mathrm{~km}$ ) sedimentary sequence is located in the ZDD, with thicknesses of 6-8 km in other parts of the Central Mozambique Basin (Castelino et al.
2015; Mahanjane 2012; Salazar et al. 2013; Salman and Abdula 1995).

The sediment discharge history of the Zambezi River is characterized by considerable variability since the Mesozoic (Castelino et al. 2015; Walford et al. 2005). Those authors correlated surges in sediment accumulation during Late Cretaceous (75-65 Ma), Oligocene (34-24 Ma) and Late Miocene- Pleistocene (5-1.8 Ma) times to episodes of epeirogenic uplift onshore (Partridge and Maud 1987) and increases in catchment area (Walford et al. 2005). Prior to the late Miocene-Pleistocene, the parts of the present-day Zambezi catchment area currently upstream of the Victoria Falls (Fig. 2), delivered sediment to the Limpopo further south (Goudie 2005). Apatite fission track analyses in northern Namibia show accelerated cooling periods during the Cretaceous, at $\sim 70 \mathrm{Ma}$ and $110-90 \mathrm{Ma}$, that postdate the rifting related to the opening of the Atlantic ocean (Brown et al. 2014; Wildman et al. 2016). These cooling periods have been interpreted in terms of rock uplift, and the subsequent denudation of the uplifted surface has been estimated to between $4.5 \mathrm{~km}$ along the Namibian margin to $1 \mathrm{~km}$ inland (Brown et al. 2014; Gallagher and Brown 1999; Tinker et al. 2008). The effect of this denudation is observed in sedimentary basins along the southwest Atlantic margin where a peak sediment influx is recorded at between 80 and 70 Ma (Dingle and Hendey 1984; Rouby et al. 2009). Similarly, in the Malawi Basin in Northern Mozambique, apatite fission track analysis is interpreted in terms of enhanced denudation around $\sim 75 \mathrm{Ma}$ (Daszinnies et al. 2009). An increase in sediment input in the Mozambique Basin can therefore be linked to what was apparently a widespread phase of Late Cretaceous uplift in southern Africa and resulted in fan development off the Zambezi during Late Cretaceous-Eocene times (Castelino et al. 2015; Walford et al. 2005). Using shallow geophysical and coring-based data, several studies (Droz and Mougenot 1987; Kolla et al. 1980b) describe how the present Mozambique

Table 1 Dimensions of some well-studied modern-day fans (source: Curray et al. 2003) and the dimensions of Mozambique Fan (1) (Kolla et al. 1980b) (2) (Castelino et al. 2016; this study)

\begin{tabular}{|c|c|c|c|c|c|c|}
\hline Fan & Length (km) & Width $(\mathrm{km})$ & Area $\times 10^{3}(\mathrm{sq} . \mathrm{km})$ & Max Thickness (m) & $\begin{array}{l}\text { Water depth } \\
\text { apex }(\mathrm{m})\end{array}$ & $\begin{array}{l}\text { Water } \\
\text { depth } \\
\text { distal (m) }\end{array}$ \\
\hline Bengal and Nicobar & 3800 & 2000 & $?$ & 16,500 & 1400 & 5500 \\
\hline Indus & 1500 & $<960$ & 1100 & $>9000$ & 1500 & 4600 \\
\hline Mozambique & $1800(1)$ & $400(1)$ & $<720(1)$ & $8000(2)$ & $1600(2)$ & $5000(2)$ \\
\hline Amazon & $>700$ & $250-700$ & 330 & 4200 & 1500 & 4800 \\
\hline Mississippi & 540 & 570 & $>300$ & 4000 & 1200 & 3300 \\
\hline Monterey & 400 & 250 & 75 & 2000 & 1280 & 4570 \\
\hline Astoria & $>250$ & 130 & 32 & 2200 & 1140 & 2840 \\
\hline La Jolla & 40 & 50 & 1.2 & 1600 & 550 & 1100 \\
\hline
\end{tabular}


Fan morphology is built of sediments supplied via secondorder turbidite systems that begin as a series of valleys on the East African and Madagascan shelves (e.g., the Zambezi, Serpa-Pinto, Limpopo-Save, Labathie and Tsirihibina valleys; Fig. 1). They divide the eastward flowing Zambezi turbidite system originating on the Mozambican shelf into three parts, namely, (1) the slope-incising network of canyons referred to as the Zambezi Canyon that precedes (2) the Zambezi Valley, which erodes shallow strata on the continental rise and meanders south at $41^{\circ} \mathrm{E}$ before (3) giving way further downstream to a stable, almost N-S oriented feature termed the Zambezi Channel. The Zambezi Channel at the present day displays features typical of a channel-levee system with thick sediment deposits on either side of the channel but appears to be inactive and infilled with chaotic or sheeted sediment deposits. Prior to the Zambezi deposits, the sediment deposits of the SerpaPinto Valley oriented in a north-south direction along the Davie Ridge dominated the Upper Fan from Oligocene to Miocene (Droz and Mougenot 1987). Piston core data from the Mozambique Fan indicate a terrigenous origin of the Quaternary sediments, for the most part delivered presumably via the Zambezi Channel (Kolla et al. 1980a, b). Droz and Mougenot (1987) suggested early on that the upper reaches of sediment dispersal pathways over the shelf are relatively unstable, but their work was restricted because of poor quality and insufficient seismic data. Studies on sediment cores show a strong variability of sediment dispersal to the north along the shallow margin in the Holocene times linked to the flooding of the shelf after Last Glacial Maximum (LGM) (Beiersdorf et al. 1980; Schulz et al. 2011; Van der Lubbe et al. 2014).

\section{Oceanographic setting}

At the present day, a complex oceanographic setting controls the deposition of the fan sediments. The Mozambique Current (MCE), a branch of the North East Madagascar Current (NEMC), is the most prominent water mass transport in the channel contributing to a net southward flow of $15 \mathrm{~Sv}$. (Fig. 2). Large anti-cyclonic eddies, which reach as deep as the base of the Mozambique Channel, dominate the southward propagation of the current through the Mozambique Channel, and feed into the Agulhas Current further south around $30^{\circ} \mathrm{S}$ (Ridderinkhof and De Ruijter 2003; Schouten et al. 2003). Along the southern East African Margin a weak northward flowing Mozambique undercurrent, at 1500-2500 m water depth, carries $5 \mathrm{~Sv}$ of intermediate and deep water masses originating from the Atlantic ocean (Antarctic Intermediate Water-AAIW and North Atlantic Deep Water-NADW) (de Ruijter 2002; Wiles et al. 2014).

\section{Data and methods}

We use nine interpreted multi-channel seismic (MCS) profiles totalling $2200 \mathrm{~km}$ in length recorded with a G-gun cluster (volume: 42.6-67.2 L at $145 \mathrm{bar}$ ) and $3000 \mathrm{~m}$ streamer (240 channels, $12.5 \mathrm{~m}$ hydrophone spacing). These data were acquired in 2007 as part of the MoBaMaSis project (Castelino et al. 2015; Reichert 2007) and were subsequently processed using standard procedures for frequency filtering with $10-60 \mathrm{~Hz}$ bandpass filter, multiple suppression and post-stack F-K migration (Fig. 3). Shipborne swath bathymetry acquired during the expedition and a subsequent expedition (Jokat 2014), in addition to a global bathymetric grid (GEBCO) are examined to study the morphology of the ancient and modern turbidite systems at different times since Late Cretaceous. Lithostratigraphic information was incorporated from previous studies (Castelino et al. 2015; De Buyl and Flores 1986; Droz and Mougenot 1987) having been compiled from the nearby offshore wells Zambezi-1 and Zambezi-3 (Fig. 3) and other onshore wells. The attendant seismic stratigraphy is described by Castelino et al. (2015), and consists of six units labelled MBSU 1-6 that correspond to packages of Jurassic, Lower Cretaceous, Upper Cretaceous, Paleogene, Miocene and Quaternary sediments respectively used as background information for this study (Table 2).

\section{Results-Morphology of the ancient turbidite systems-}

The part of the Upper Mozambique fan originating from the Zambezi comprises of at least three prominent pathways or turbidite systems that were successively active for tens of millions years since Late Cretaceous according to the seismic stratigraphy. (1) The oldest of these systems is located close to the continental shelf to the north of the present-day mouth of the Zambezi and was active in the Late Cretaceous until at least Eocene. We refer to its deposits as the Zambezi Fan (Figs. 4, 5, 6). It overlies the continuous Top Lower Cretaceous Unconformity. The evolution of the fan can be interpreted in profiles BGR07-201, BGR07-202 and BGR07-203 (Figs. 4, 5, 6). Close to the shelf edge, several valleys or channels are interpreted from their fills and slope-apron deposits (Fig. 4, BGR07-203). The dispersal of sediments via basin floor fan (BFF) is interpretable in BGR07-202 (Fig. 5), in the form of a number of lenticular convex-upward sediment wedges (4-6 s TWT). In line BGR07-201, several of these wedges are located in the deeper channel where they are juxtaposed with mass wasting deposits originating on the continental rise (Fig. 6, 5-5.5 s TWT). The maximum sediment thickness at the peak of the fan exceeds $1 \mathrm{~km}$ in all profiles where 


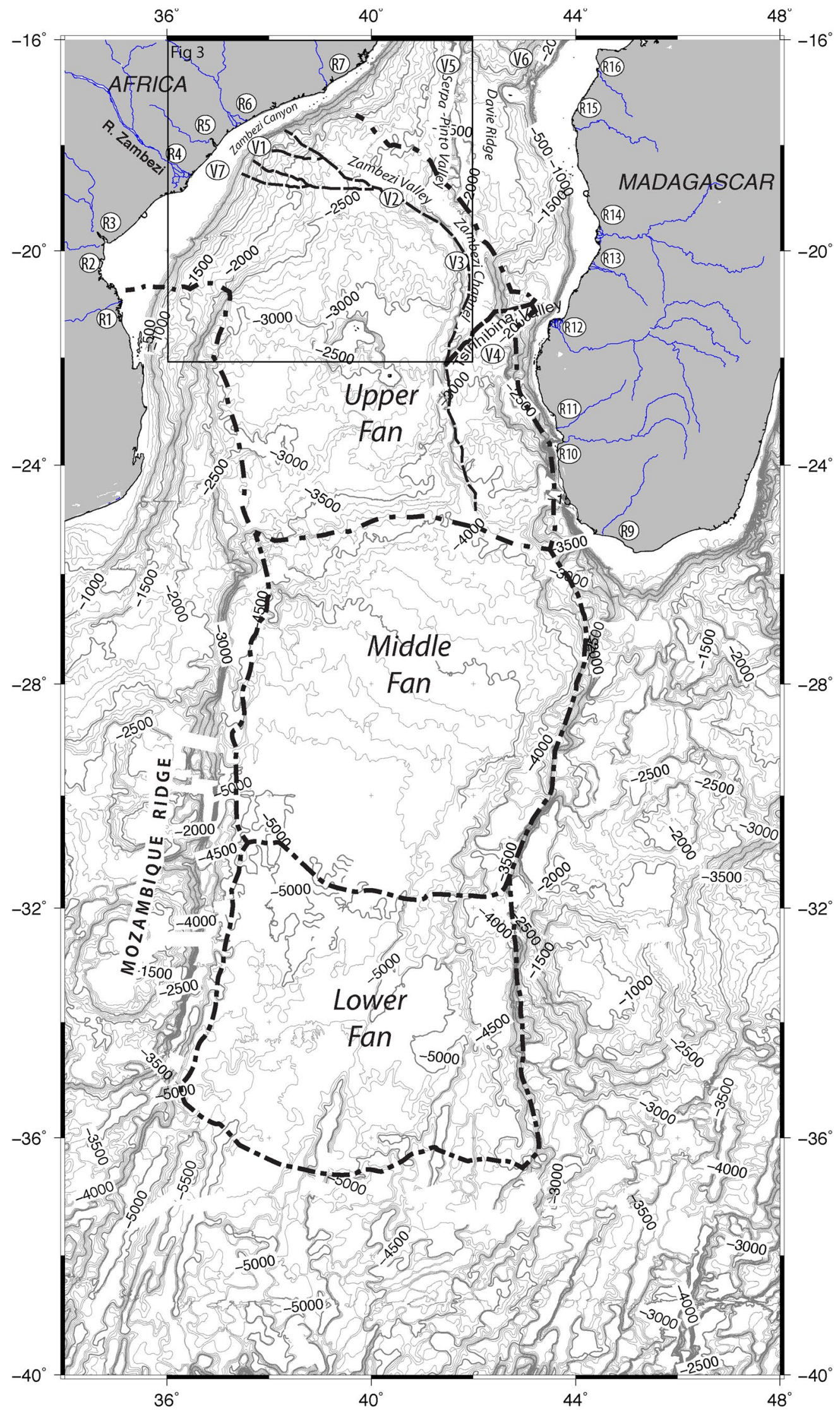


4Fig. 1 GEBCO Bathymetric map of Mozambique Basin showing the extent (dot-dash line) and different parts of the Mozambique Fan (identified by Kolla et al. (1980a, b). The depressions of the Tsiribihina, Serpa-Pinto and Zambezi Valleys that feed the Upper Mozambique Fan can be observed in the bathymetry. The Zambezi Channel (dashed line) with a broad meander disperses into the Middle Fan. Abbr: R1=R. Save; R2=R. Buzi R3=R. Pungwe R4=R. Zambezi $\mathrm{R} 5=\mathrm{R}$. dos Bons Sinais, R6=R. Licungo R7=R. Ligonha R8=R. Menarandra R9=R. Onilahy $10=R$. Fiherenana R11=R. Mangoky $\mathrm{R} 12=\mathrm{R}$. Morondava R13=R. Tsiribihina R14=R. Manambaho $\mathrm{R} 15=\mathrm{R}$. Maningoza R16=R. Mahavavy sud; V1=Zambezi Canyons; V2 Zambezi Valley; V3=Zambezi Channel; V4=Tsiribihina Valley; V5 $=$ Serpa-Pinto Valley; V6 $=$ Labathie Valley; V7 $=$ ChindeZambezi Canyon

they intersect. The thickest parts of the younger sediment wedges are located progressively further south, revealing that the depocentre migrated southwards. While the northern fan lobe grows slowly during this period, the southern fan lobe aggrades and migrates southwards making an almost triangular shape (Fig. 6; SP 1400-2200).
After Oligocene times, the sediment delivery system switched to the south over Sofala Zambesia Bank (SZB), incising several valleys and channels in the process (Figs. 7, 8). The Sofala Zambezia bank represents the present-day shelf that has prograded and aggraded since Miocene times (Fig. 3). Further down-slope, this system forms a large channel-levee complex on the submarine terrace over Beira High. We term this feature the Beira High Channel-levee Complex (Figs. 7, 8). The Beira-High Channel-levee complex structure is observed in profiles BGR07206 and BGR07-208 (Figs. 7, 8; 3-5 s TWT). Both profiles show two distinct depositional patterns that stack up to $2 \mathrm{~s}$ TWT in thickness and up to $80 \mathrm{~km}$ wide. The lower deposits (Phase 1) are composed of several channels and smaller submarine fan lobes overlying canyons that were incised during the mid-Oligocene marine regression. In the upper unit (Phase 2), a single deep incising valley with high levee deposits is observed. Simultaneously prograding-aggrading clinoforms at the shelf with turbidity deposits onlap the

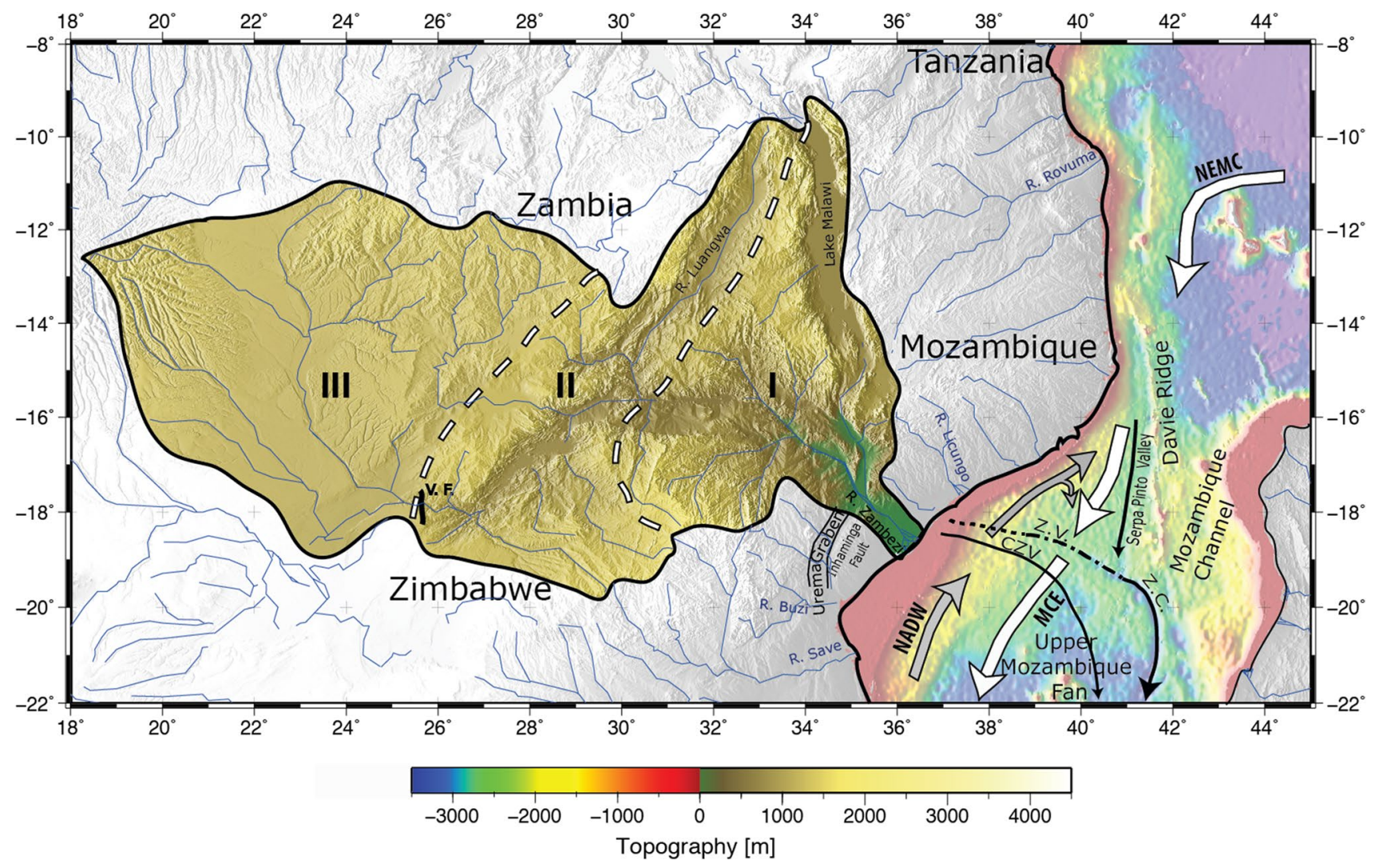

Fig. 2 Map of the present-day catchment of the Zambezi River and oceanic circulation in the basin. The Catchment area is divided into 3 parts, i.e. lower (I), middle (II) and Upper (III). The middle catchment area was captured during the Late Cretaceous Uplift while the upper catchment area that previously drained into the Limpopo Basin further south, joined the Zambezi River during the Pliocene-Pleisto- cene uplift. A branch of the North East Madagascar Current (NEMC) flowing along the northern margin of Madagascar enters the Mozambique Channel where southward flowing anti-cylonic eddies (MCE) dominate the channel (white arrow). A weak Antarctic Intermediate Water and North Atlantic Deep Water (NADW) current flow northwards along the Mozambican margin (grey arrow) 
Fig. 3 Location of the seismic lines used in this study. The Sofala-Zambesia Bank (SZB) forms a prograding sequence over the Zambezi Delta Depression (ZDD). The age constraints for seismic horizons are derived from well-data Zambezi-1 (Z-1) and Zambezi-3 (Z-3) that lie on profile BGR07-205

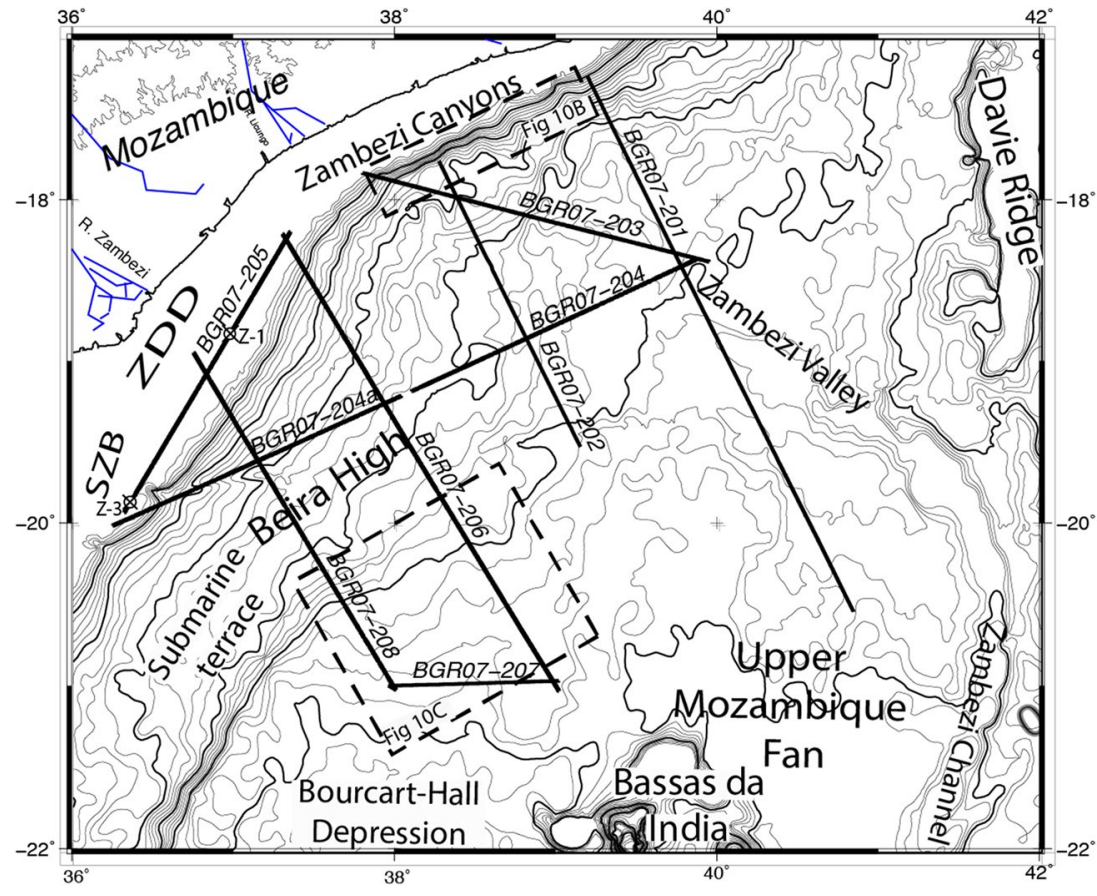

levee flanks. The deep channel is filled in with well-stratified sediment deposits.

Since Late Miocene, a significant part of the sediment load from the Zambezi was delivered via the Zambezi Valley directly to the Mozambique fan in the deeper basin by bypassing the shelf. The morphology of the Zambezi Channel (Figs. 1,3) is very well defined in GEBCO bathymetry. Contrary to the previous study of Droz and Mougenot (1987), seismic profiles (Figs. 4, 5, 6, 9) and ship-borne swath bathymetry (Fig. 10) reveal several tributary valleys and canyons that merge into a sing Para_FL le valley around $40^{\circ} \mathrm{E}$ (referred to as Zambezi Valley) where it starts to resemble a channel-levee system (referred to as Zambezi Channel) with thick sediment deposits on either side. The valley erodes the Miocene and younger sediments and is characterized by steep walls and slope failures. The valley itself appears to be in-filled with chaotic or sheeted sediment deposits (Fig. 9). Several closely spaced canyons (Zambezi Canyon) originating on the shelf slope sharply incise the seafloor (Figs. 5, 6, 10) and merge into subtle valleys on the continental rise.

\section{Discussion}

In the following section, we describe the evolution of the turbidite systems of the Upper Mozambique Fan chronologically starting from Late Cretaceous until present. The controls on the architecture of the turbidite system are simultaneously discussed.
Table 2 Generalized stratigraphy of the Mozambique basin (modified from De Buyl and Flores 1986) and seismic stratigraphy adapted from Castelino et al. (2015) used in this study

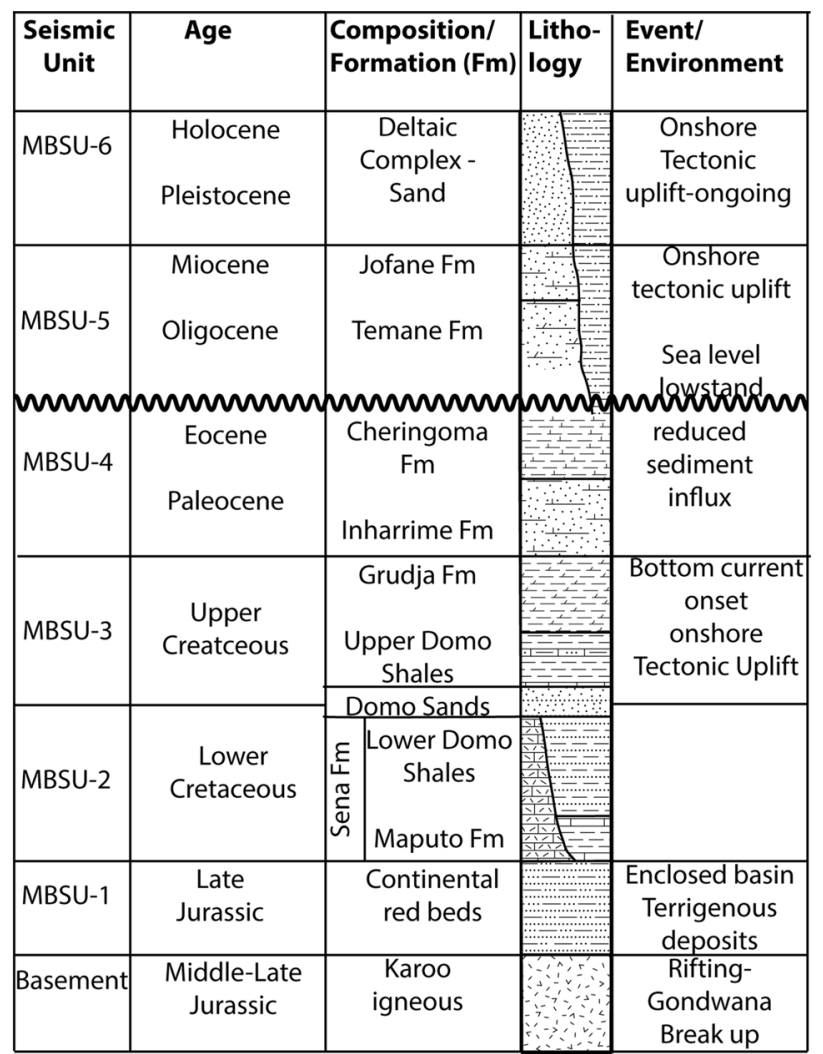



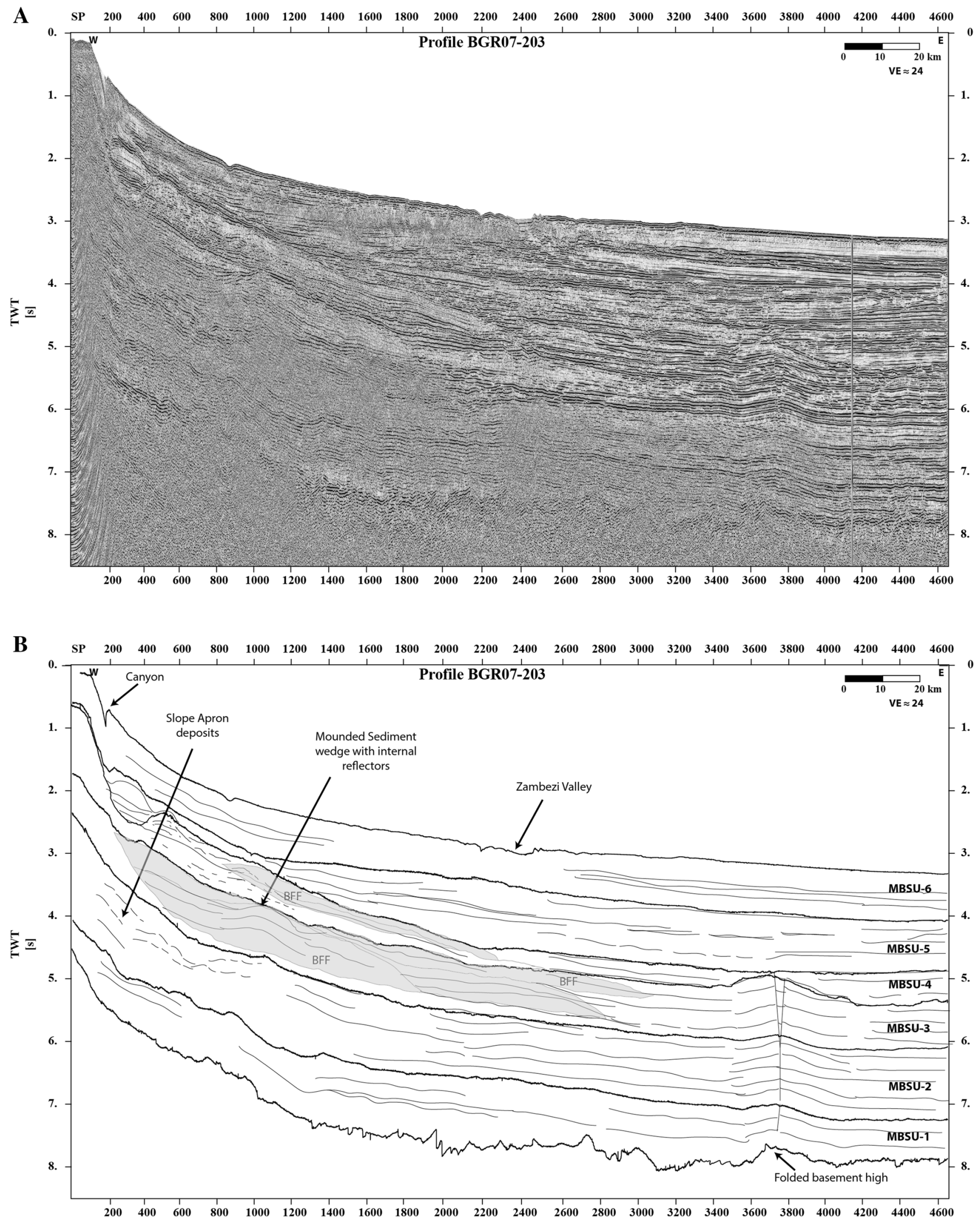

Fig. 4 a Uninterpreted seismic profile of BGR07-203. b Line drawing of seismic line BGR07-203. Sediment mounds associated with slope-apron submarine fan deposits are observed in the section. Shelf incising canyons are located on the seafloor. Seismic stratigraphy MBSU-1-MBSU-6 used in all figures is described in Table 2 


4Fig. 5 a Uninterpreted seismic profile of BGR07-202. b Line drawing of interpreted seismic profile BGR07-202 (modified from Castelino et al. 2015). Most of MBSU-3 unit comprises of fan lobes. During the early phase when tectonic activity triggers fan development, the lobes have comparable development. During the later phase when sediment supply is the primary control, the right (southwestern) lobe accumulates faster and migrates southwards under the influence of bottom currents. The seafloor is incised by valleys at several locations that transport sediment load from the shelf into the channel

\section{Controls on Late Cretaceous-Eocene fan development}

Partridge and Maud (1987) inferred epeirogenic uplift of southern Africa by about $1000 \mathrm{~m}$ around $\sim 90 \mathrm{Ma}$ on the basis of onshore landscape analysis. This has been subsequently corroborated by apatite-fission track analysis of samples along the Atlantic margin in Nambia and South
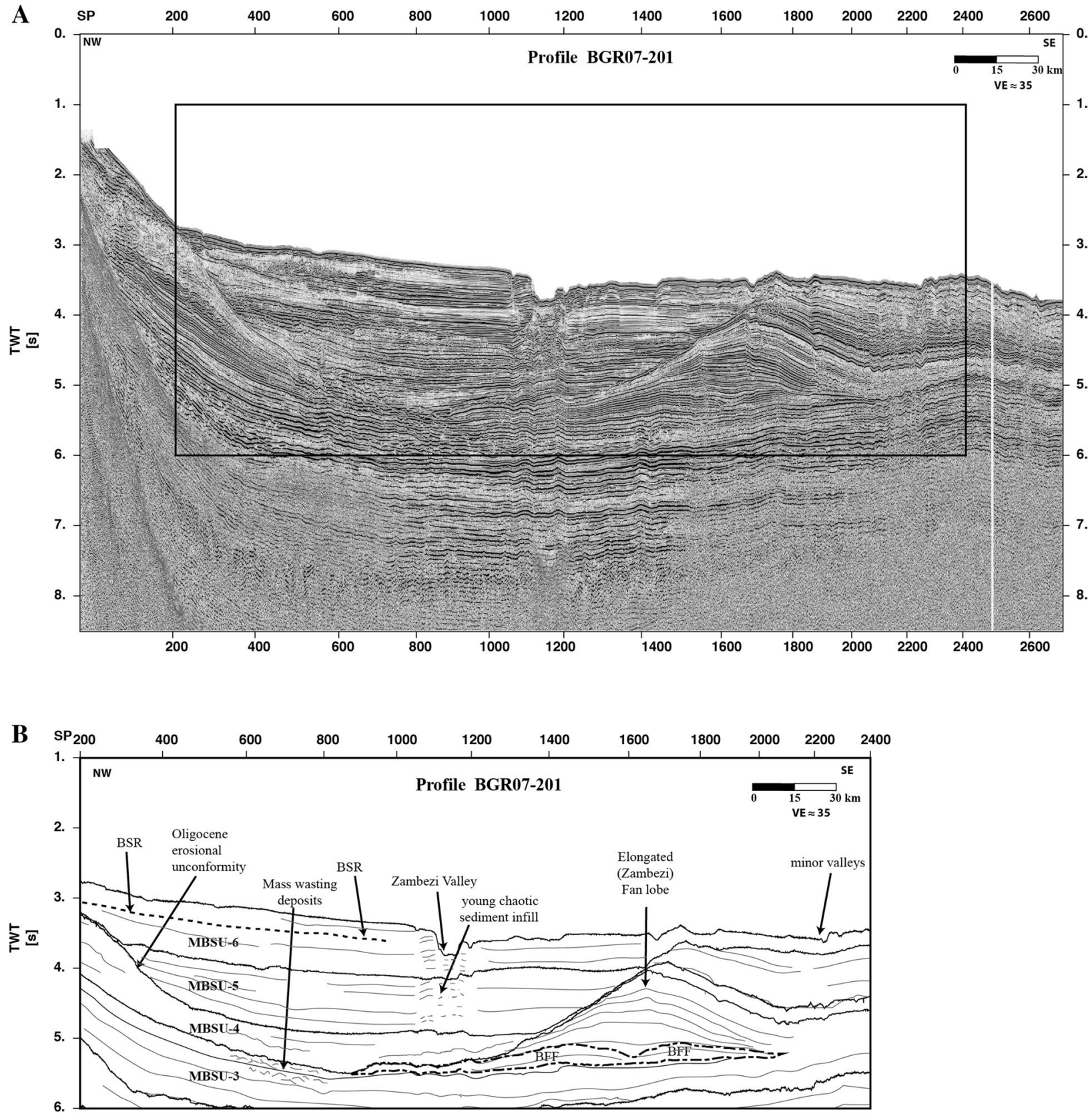

Fig. 6 a Uninterpreted seismic profile of BGR07-201. The black box indicates the extent of the interpreted section. b Line drawing of interpreted seismic Profile BGR07-201 (modified from Castelino et al. 2015). Submarine fan development begins in unit MBSU-3 (Late Cretaceous) where mass wasting deposits are followed by development of Basin Floor Fans (BFF). The Zambezi valley that fed the Upper Mozambique Fan is characterized by steep walls, slope failure faults and chaotic sediment infill. BSR (Bottom Simulating Reflector) along the profile is identified on the continental rise indicating the presence of gas hydrates and free gas below it 

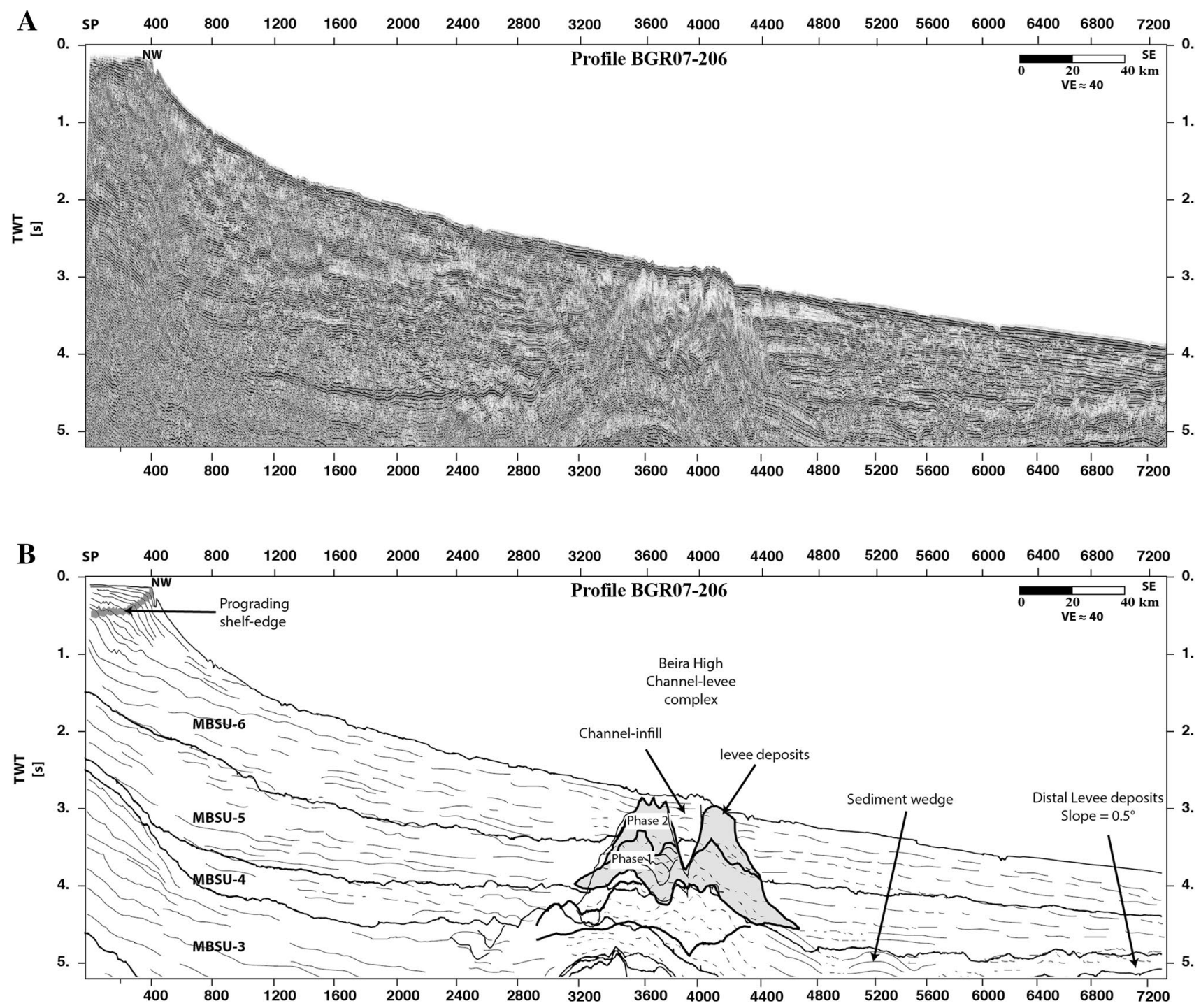

Fig. 7 a Uninterpreted seismic profile of BGR07-206. b Line drawing of seismic line BGR07-206. The top-MBSU-4 reflector outlines several incised valleys that are filled with younger sediments. The massive Channel-valley complex above Beira High is illustrated in a grey shade

Africa (Brown et al. 2014; Wildman et al. 2016) and along the Malawi Rift system and in northern Mozambique (Daszinnies et al. 2009; Emmel et al. 2011), where fission track analysis show distinct period of cooling in the Late Cretaceous around $\sim 75$ Ma. This uplift could have resulted in a regional change in sea level affecting at least the shelf region over a relatively short time span. Nelson et al. (2011) use precise radiocarbon dating to report how rapid Holocene sea level changes result in the formation of mass transport deposits globally. The presence of Cretaceous mass transport deposits along the Mozambican continental shelf (e.g., Fig. 6-SP 500-800; $5-5.5 \mathrm{~s}$ ) is consistent with the idea of regional sea level change at that time or alternatively, to seismicity due to onshore uplift. Besides these slope failures, basin floor fans developed at the continental rise where they were fed by shelf canyons and gullies with sediments eroded from the shelf. We refer to the mass wasting deposits and basin floor fan (BFF) development as early phase of fan development that is controlled by tectonic activity (Figs. 4, 5, 6 ). The seismic lines of our study cover only the lower fan deposits. Onshore studies based on well data show the presence of fan deposits (De Buyl and Flores 1986; Nairn et al. 1991; Salman and Abdula 1995) that indicate the Palaeocene-Eocene shelf and Zambezi Fan were located much further landwards than today's (Fig. 11a). The Late Cretaceous uplift was accompanied by largescale denudation of the African surface and a growing Zambezi catchment area (Fig. 2), which led to increased sediment material transport. Contemporaneous increases 

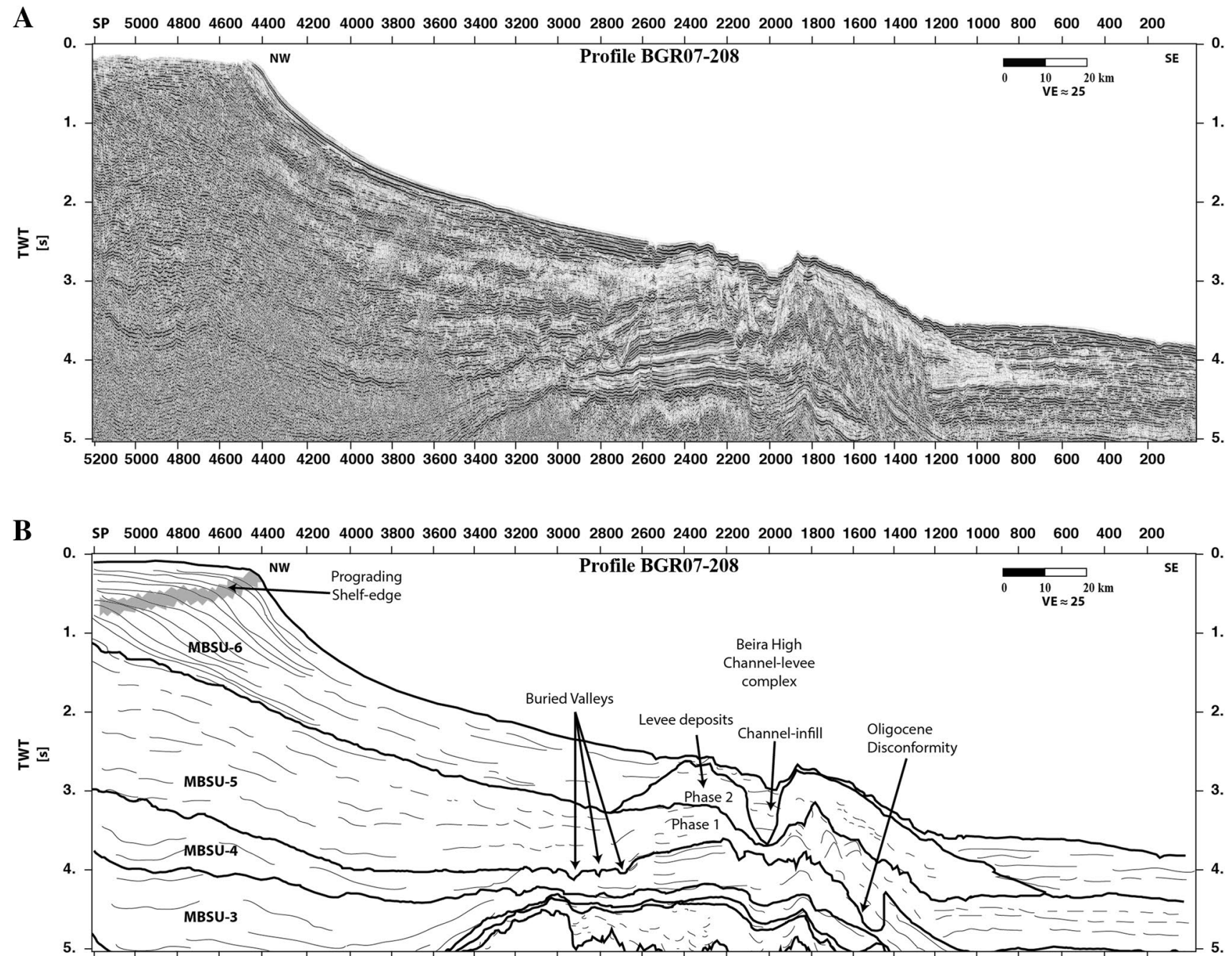

5200500048004600440042004000380036003400320030002800260024002200200018001600140012001000800600400200

6. -

Fig. 8 a Uninterpreted seismic profile of BGR07-208. b Line drawing of seismic line BGR07-208 showing the continuation of the Channel-valley complex above Beira High. The top reflector of

in sedimentation rates in other southern African margin depocentres (e.g., Orange River Delta (Rouby et al. 2009), Outeniqua Basin (Tinker et al. 2008) and Limpopo Delta (Said et al. 2015)) are also attributed to Late Cretaceous uplift. In Namibia, up to $1 \mathrm{~km}$ on the Atlantic margin and $4.5 \mathrm{~km}$ inland have been eroded (Wildman et al. 2016). Similar denudation has been reported in northern Mozambique and in the Zambezi catchment area (Daszinnies et al. 2009; Partridge and Maud 1987).
MBSU-4 is strongly eroded unconformity and younger chaotic sediments fill the erosive topography. To the east, deep-sea sedimentation on laps the levee deposits

The average sedimentation rate in the Mozambique Basin increased almost two fold during this period, peaking at in excess of $75 \mathrm{~mm} / \mathrm{kyear}$. Previous studies have shown that the consequent increase in sediment influx (Castelino et al. 2015; Walford et al. 2005) led to the deposition of upper or middle-fan deposits over the older deposits of the lower fan as it grew further out into the channel until the Eocene (Fig. 4). We refer to these deposits as the 'Late phase' of fan development where sedimentation 
volume and type is the primary control on the fan deposits. Upslope, the south-western (right) fan lobe shifted southwards by discrete steps while accumulation on the north-eastern lobe was significantly less (Figs. 5, 6). This can be interpreted as a complex product of shelf margin build-up moving landward after the post-uplift subsidence and the influence of north-south bottom current.

\section{Oligocene-Miocene turbidite system over Beira High}

By the end-Eocene, planation of the South African topography, whose result is referred to as the Post African I surface (Partridge and Maud 1987), deprived the African rivers of sediments. In the offshore seismic data, this might be documented by the base Oligocene (Top MBSU-4) reflector unconformity, which relates to a hiatus and global eustatic sea level fall after Eocene to mid-Oligocene times (Figs. 4, $5,6,7,8)$. In this period, the delta foreset retreated landwards by almost $100 \mathrm{~km}$ as the shelf in the ZDD became subaerially exposed (De Buyl and Flores 1986; Droz and Mougenot 1987). Sedimentation rates were almost negligible in the shelf region. Consequently, a significant quantity of sediments on the shelf and the submarine terrace over Beira High were eroded by incising canyons and valleys in the ZZD and most likely transported to the mouth of the valley in the deeper basin. After the marine regression phase, sediment input into the basin was revived by renewed elevation of African surface topography by 150-300 m during the Miocene (Burke 1996; Burke and Gunnell 2008; Castelino et al. 2015; Partridge and Maud 1987; Walford et al. 2005). Uplift along the Ovambo-Kalahari-Zimbabwe Axis rejuvenated the southern African drainage network, initiating a new cycle of erosion in the continental interior and accompanying increased sediment discharge in the Limpopo and Congo deltas (Moore et al. 2009; Roberts and White 2010; Said et al. 2015). On the Mozambique Fan, too, topset reflector patterns and welldeveloped clinoforms at the shelf edge indicate an increase in sediment supply and accommodation space by subsidence and sediment compaction (Fig. 7- SP 0-800, 0-1.5 s TWT; Fig. 8-SP 5200-4100, 0-1.5 s TWT). However, the sediment volume flux outpaced the increase in accommodation space resulting in strong prograding sequences and outbuilding of the system. The chaotic and discontinuous character of sediment deposition and development of multiple channels indicates a high-energy environment. During the subsequent phase, a massive channel levee complex formed over Beira High (Fig. 7,8; Phase 2) with a deep channel. We associate this change in depositional regime to Middle-Miocene reactivation of the northwest - southeast oriented Inhaminga fault system that cuts the older northwest-southeast Zambezi Graben, producing topography that diverted the sediment load of the Zambezi further south over Urema Graben towards Beira for a short period of time (De Buyl and Flores 1986; Flores 1973) (Fig. 11c). The change in the deltaic environment due to sediment supply from further south triggered the development of the Beira High Channel-Levee Complex. Numerical and experimental models show that the initiation of channel-levee systems requires specific combinations of grain size, slope, and a mechanism for the production of regular turbidity currents at the mouths of canyons (Imran et al. 2002, 1998). Palaeo-climatic studies indicate shifting African monsoon-like conditions along the eastern and southeastern African Margin during Late Neogene (Maslin and Christensen 2007), implying strong seasonal variation in precipitation that could have acted to produce turbidity currents. Activity in the channel ceased or reduced when

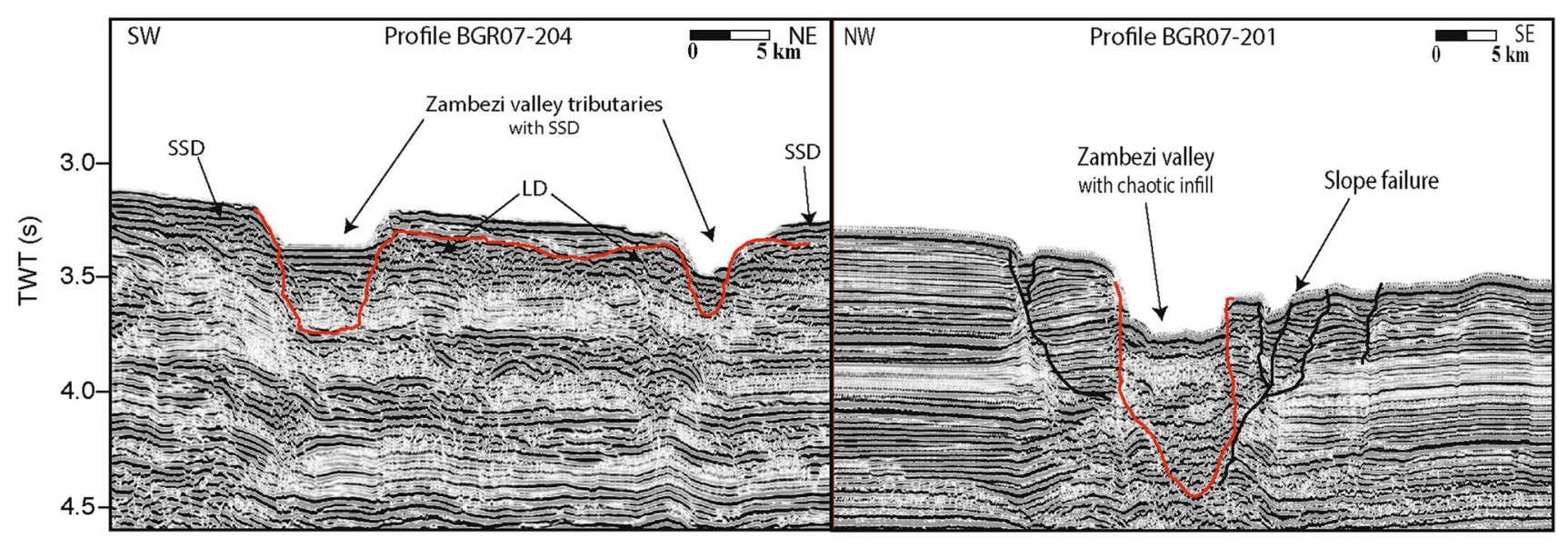

Fig. 9 Seismic profiles across the Zambezi Valley (right) and its tributaries (left) in the Mozambique Basin are outlined in red. The sidewalls of the tributaries are oversteepened and are infilled with chaotic sediment deposits overlain by sheeted sediment drape. The Zambezi Valley flanks show several faults related to slope failure. $L D$ levee deposits, $S S D$ sheeted sediment drapes 
Fig. 10 a Bathymetric map of the Mozambique Basin showing ship-borne multibeam data acquired during the expedition with GEBCO 2014 in the background. b Ship-borne bathymetry along the continental slope in the north shows several canyons indenting the seafloor. c Submarine valleys at the base of the submarine terrace that provides pathways for the sediment load to directly bypass the shelf



B

the course of the Zambezi was later restored close to its present-day position. The channel was subsequently filled with well-stratified sediments under low energy conditions or a subsequent wavering phase of the turbidite system.

\section{Late Miocene-Pliocene/Pleistocene development of the Zambezi Channel system}

The Zambezi Valley (Figs. 6, 9) has incised through Miocene sediment packages, implying its sedimentary system is not older than Miocene. Using our profiles, it is difficult to make observations that enable us to precisely date the onset of turbidity current activity in the Zambezi Valley during the Miocene. However, further down the channel, Droz and Mougenot (1987) found that the Serpa-Pinto Valley (Fig. 1) deposits of Oligocene-Early Miocene age underlie the Zambezi Channel deposits. This would constrain the age of Zambezi valley to around the middle Miocene or later, to coincide with East African rifting onshore Mozambique and the Zambezi's adoption of its present-day course. In this case, the sediment load that was previously transported over Beira Channel-Levee system would have subsequently diverted north along the shelf before being flushed down the Zambezi canyons and valley and into the Zambezi Channel where it is deposited as levee deposits.

Chaotically-stratified sediments overlain by sheeted drapes that fill the valley (Fig. 9) suggest reduced turbidity current activity in the present-day valley. This supports Droz and Mougenot's (1987) attribution of the absence of Pliocene sediments on the levee further south (Kolla et al. 1980b) to reduced activity, rather than erosion by deep water currents, in the channel. Canyons may achieve stability through successive slumps (Coleman et al. 1983) or by waning turbidity current activity. Following this rationale, slump deposits or fine pelagic and hemi-pelagic sediments gradually fill canyons. The chaotic sediments sediment deposits in the valley observed in the profiles (Fig. 9) are most likely slump deposits related to stabilization of the system with only a small fraction of the sediment load discharged by the rivers being deposited as sheeted drapes post-stabilisation. On the other hand, sedimentation rates in the basin have continuously increased since Miocene times (Castelino et al. 2015; Walford et al. 2005), accompanying continental uplift by almost $1000 \mathrm{~m}$ and doubling of the Zambezi catchment area (Walford et al. 2005). In line BGR-203, shallow valley incisions filled with sediments are observed that could be upslope manifestations of the Zambezi Valleys. However, the continuations of these valleys are beyond the resolution of the bathymetry. The last 20,000 years of have been strongly affected by sea level rise and flooding of the shelf transporting sediment further northwards on the shelf (Schulz et al. 2011; Van der Lubbe et al. 2014; Wiles et al. 2017). If similar conditions also existed during the Pliocene then canyons would have been starved of sediments during sea level lowstand causing the inactivity in the Zambezi Valley.

\section{Present-day source to sink pathway}

Sedimentation rates in the Zambezi delta inferred from isochore maps show a recent increase in the sediment load of the Zambezi to in excess of $200 \mathrm{~mm} / \mathrm{kyear}$ averaged over last $5 \mathrm{Ma}$ (Castelino et al. 2015; Walford et al. 2005). Higher sedimentation rates (750-900 mm/kyear) are observed in the sediment cores on the shelf slope in front of the Zambezi mouth and lower rates ( $>500 \mathrm{~mm} / \mathrm{kyear}$ ) further north since 20,000 b.p.(Van der Lubbe et al. 2014). The associated sediment transport pathways over the shelf to the deeper basin are unfocused and difficult to determine (Schulz et al. 2011). This lack of stability is related to sea level rise and subsequent flooding of the shelf since LGM when parts of the shelf were sub-aerially exposed and the sediments were transported via gullies and canyons directly to the deeper basin. Beiersdorf et al. (1980) show grabenlike structures that are filled with Pliocene sediments on the shelf in the Zambezi Delta. While significant quantities of sediment are deposited on the shelf, it is suspected that sediments are also transported to the Upper Mozambique Fan via the re-excavated Chinde-Zambezi Graben (Droz and Mougenot 1987) (Fig. 10). The presence of Pliocene sediments lead Droz and Mougenot (1987) to suggest that this graben trapped sediments and starved the Zambezi canyon that fed the Zambezi valley. Seismic profiles (Figs. 4, 5, 6) and new bathymetry data (Fig. 10b) show the presence of several closely spaced canyons along the shelf north of the Zambezi mouth and northwest-southeast oriented valleys originating close to the shelf and meandering southwards east of Beira High (Fig. 10c). This supports the recent hypothetical models that propose a northward transport of a significant fraction of sediment load over the shelf based on short sediment core data (Schulz et al. 2011) and a compartmentalized tripartite regime supplying sediments into the Angoche Basin, the Bourcart-Hall Depression and the Zambezi Valley-Channel (Wiles et al. 2017). This study along with other recent studies supports the hypothesis of Droz and Mougenot (1987) that a large fraction of the sediments bypass the shelf and flow south directly into the Mozambique Channel. This valley meanders at the base of the slope where the gradient of the slope changes before entering the Bourcart-Hall Depression west of the Bassas da India and Europa islands (Fig. 10c).

\section{Role of oceanic circulation}

It is worthwhile to note the presence of fully developed channel-levee systems flanked by thick (almost $2 \mathrm{~s}$ TWT) 
A
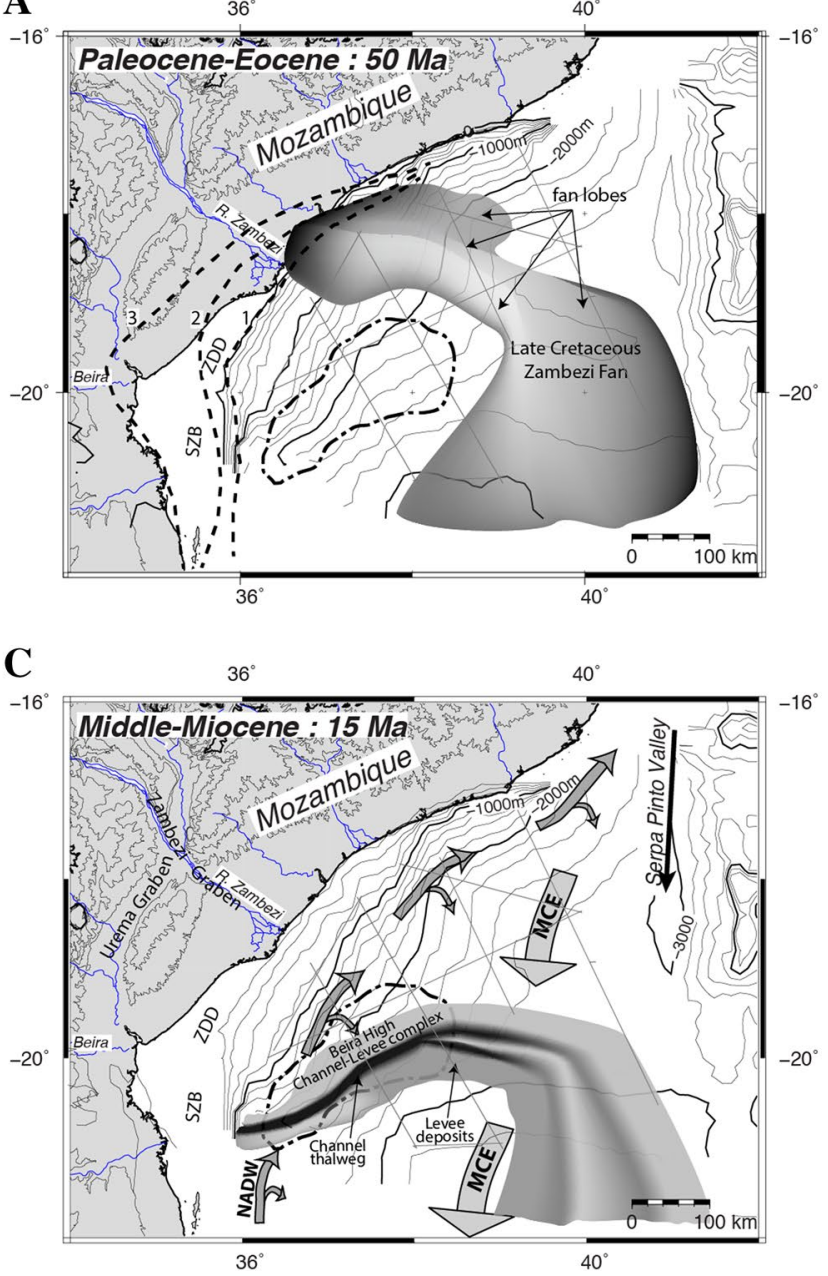

Fig. 11 The hypothesized schematic sketch of the submarine fans and turbidite systems in the Mozambique Basin showing the minimum extent of turbidite deposits (grey shades) and their feeding canyons and valleys (black). The size and geometry are interpreted from seismic profiles. The contour lines (depth in meters) show the palaeo-bathymetry for the given age (Castelino et al. 2016) a Minimum extent of the Zambezi Fan during Paleocene-Eocene. The fan consists several fan lobes are stacked on top each other that migrates southwards around Beira High (dash-dot line). The dashed lines indicate retreating palaeo-shelf edge (Salman and Abdula 1995) 1- Paleocene; 2- Early Eocene; 3- Middle-Late Eocene. b Turbidite system during Late Oligocene -Early Miocene switched further south.

levee deposits over Beira High during Miocene and Zambezi Channel, during middle-late Miocene and their absence or poor development on other valleys during other times. Numerical and analogue models for investigating the role of turbidity currents in channel-levee inception have neglected the effects of contourite currents (Imran et al. 2002, 1998). In the experimental set-up, the reflection of the sufficiently fine-grained sediment load from the back wall inhibited the process of self-channelization by polluting the ambient water conditions and disturbing sediment
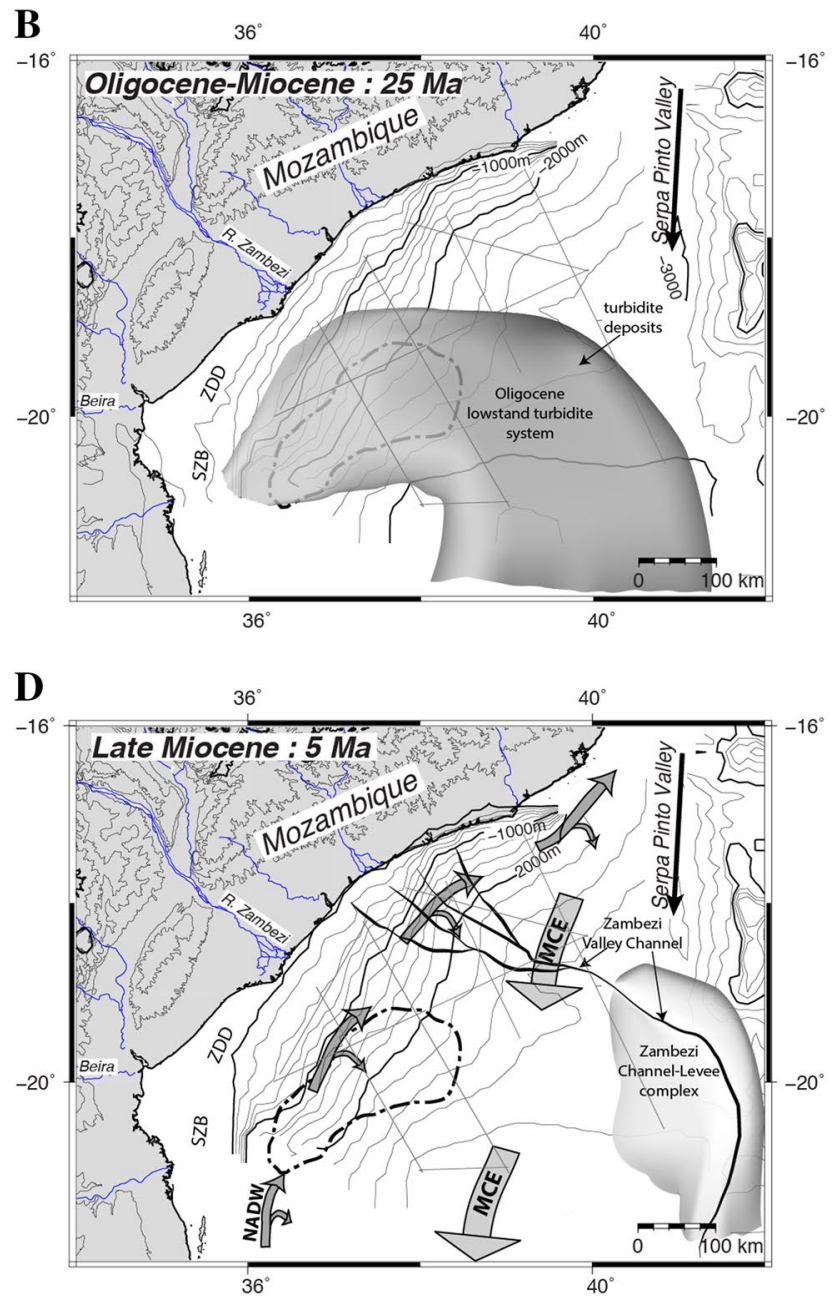

Reworked shelf sediments are transported downslope by valleys and subsequently filled and covered by younger Miocene sediments. c Beira High Channel-Levee complex that was fed by the Zambezi River when it was diverted over Urema Graben during middle-Miocene. Dark shading indicates thalweg of the channel. d Pathways of the Zambezi Valley feeding the Upper Mozambique Fan during Late Miocene. Location and orientation of bottom currents i.e., Antarctic Intermediate Water and North Atlantic Deep Water (NADW) and Mozambique Channel Eddies (MCE) that may have influenced channel-levee complex inception are indicated with grey arrows. $S Z B$ Sofala-Zambesia Bank, ZDD Zambezi Delta Depression

deposits (Imran et al. 2002) implies that the process can be easily disturbed. Both the channel-levee systems in the Central Mozambique Basin are oriented along or slightly oblique to the direction of present-day bottom currents that sweep over them i.e. the almost northward flowing NADW and AAIW over Beira high (1500-2400 m) and the southward flowing MCE over the Zambezi Channel (Fig. 2). This suggests that similar bottom currents, if active in the Miocene, would not have significantly interfered with the processes by which turbidite currents led to the inception 
and development of channel-levee complexes. Without ruling out other factors on other valleys, the Late NeogeneQuaternary feeder canyons and valleys on the continental rise are oriented almost perpendicular to the direction of bottom current propagation (NADW). It is possible that NADW inhibits self-channelization on these features despite the presence of deep incising canyons, surging turbidite loads, and steep slopes. The formation of an intermediate submarine terrace seaward of the shelf at depth range of 1000-2400 m can be attributed to dispersal of sediment overspill by northward flowing bottom currents (NADW) (Fig. 11). This also partially explains why the Zambezi Valley has such poorly developed levee deposits $(\sim 0.25 \mathrm{~s}$ TWT) (Fig. 9) and why the Zambezi Channel-levee complex is observed beyond $41^{\circ} \mathrm{E}$ where the system turns south and into the same direction as the MCE.

\section{Conclusions}

The Mozambique Fan turbidite complex is a product of several ancient and modern turbidite systems originating from the southeast African and Madagascan continent over tens of millions of years. The development of the submarine Zambezi Fan in the Mozambique Basin since the Late Cretaceous makes it one of the oldest identified depositional systems. Based on timing coincidences, onshore tectonic activity and associated uplift is the apparent mechanism and primary control on the development of the deep sea fan. Episodes of tectonic uplift during Late Cretaceous and Miocene and associated sea level change, and reactivation of rift systems has had a significant impact on the sediment delivery pathways. The increase in sediment supply into the basin, which is also a consequence of tectonic activity, has a delayed impact of a few million years on the development of turbidite system.

We identified two additional ancient turbidite systems in the basin in addition to the one ancient identified by Droz and Mougenot (1987) and present some more evidence regarding unknown aspects of the present-day turbidite system connected to the Zambezi River. The ancient systems exhibit two or more active phases controlled by tectonic activity and sediment supply during its development. From Late Cretaceous to Eocene, the Zambezi Fan developed in response to tectonic activity onshore. The early phase appears to be an instantaneous response to local sea level change. During the subsequent phase, the fan grew and prograded by increased sediment influx in to the basin. The effect of bottom currents on the dispersal of the fan is very significant in the deeper basin where the influence of turbidity currents begin to wane.

From Oligocene- to middle Miocene, the sediment supply migrated south over Zambezia-Sofala Bank. The early phase is related to the eustatic sea level change during midOligocene when several canyons eroded the shelf and submarine terraces. The subsequent uplift of Africa revived sediment input in the basin resulting in prograding clinoforms on the shelf edge. Reactivation of the Inhaminga fault system during middle Miocene changed the course of the Zambezi over the Urema Graben and resulted in the development of the Channel-Levee system over Beira High.

Ongoing rifting along the Urema Graben restored the Zambezi to its present-day orientation and significant amounts of sediments were transported northwards along the shelf by nearshore drifts where they bypassed the shelf slope and continental rise before being flushed down the Zambezi Canyon-valley system into the abyssal plains of the Mozambique Channel. Presently, the turbidite system is compartmentalized in a tripartite regime controlled by sea level variations with sediment load distributed along the entire shelf before being dispersed into the basin by valleys that extend over the submarine terrace between Zambezi Valley, Beira High and Bassas da India Island.

Acknowledgements We thank the French polar institute (IPEV) for the logistic and financial support and the captain and crew of Marion Dufresne II (IPEV) for their excellent work during the expedition. We are grateful to the contributions of Graeme Eagles, two anonymous reviewers and E. S. Mahanjane in improving the content and for the English corrections. All maps were created using GMT 5.0 (Wessel et al. 2013). GEBCO 2014: (Weatherall et al. 2015).

\section{References}

Beiersdorf H, Kudrass H-R, von Stackelberg U (1980) Placer Deposits of Ilmenite and Zircon on the Zambezi Shelf. Schweizerbart Science Publishers, Stuttgart

Brown R, Summerfield M, Gleadow A, Gallagher K, Carter A, Beucher R, Wildman M (2014) Intracontinental deformation in southern Africa during the Late Cretaceous. J Afr Earth Sci 100:20-41. doi:10.1016/j.jafrearsci.2014.05.014

Burke K (1996) The African Plate. South African. J Geol 99:341-409

Burke K, Gunnell Y (2008) The African erosion surface: a continental-scale synthesis of geomorphology, tectonics, and environmental change over the past 180 million years. Geol Soc Am Memoir 201:1-66. doi:10.1130/2008.1201

Castelino JA, Reichert C, Klingelhoefer F, Aslanian D, Jokat W (2015) Mesozoic and Early Cenozoic sediment influx and morphology of the Mozambique Basin. Mar Pet Geol 66:890-905. doi:10.1016/j.marpetgeo.2015.07.028

Castelino JA, Eagles G, Jokat W (2016) Anomalous bathymetry and palaeobathymetric models of the Mozambique Basin and Riiser Larsen Sea. Earth Planet Sci Lett. doi:10.1016/j. eps1.2016.09.018

Coffin MF (1992) The East African and Madagascar margins: stratigraphy, structure and tectonics. In: First Indian Ocean Petroleum Seminar, Proceedings of the First Indian Ocean Petroleum Seminar on Petroleum Exploration, Seychelles, 10-15 Dec 1990, pp. 325-343.

Coleman JM, Prior DB, Lindsay JF (1983) Deltaic Influences on shelfedge instability processes, In: Stanley DJ, Moore GT (eds) 
The Shelfbreak, SEPM (Society for Sedimentary Geology), Tulsa, pp. 121-137. doi:10.2110/pec.83.06.0121

Curray JR, Emmel FJ, Moore DG (2003) The Bengal Fan: morphology, geometry, stratigraphy, history and processes. Mar Pet Geol 19:1191-1223. doi:10.1016/S0264-8172(03)00035-7

Daszinnies MC, Jacobs J, Wartho JA, Grantham GH (2009) Post Pan-African thermo-tectonic evolution of the north Mozambican basement and its implication for the Gondwana rifting. Inferences from ${ }^{40} \mathrm{Ar} /{ }^{39} \mathrm{Ar}$ hornblende, biotite and titanite fission-track dating. Geol Soc London Spec Publ 324:261-286. doi:10.1144/SP324.18

de Ruijter WPM (2002) Observations of the flow in the Mozambique Channel. Geophys Res Lett 29:3-5. doi:10.1029/2001GL013714

De Buyl M, Flores G (1986) The Southern Mozambique Basin: the most promising hydrocarbon province offshore East Africa. Am Assoc Geol Bull 68:399-425

Dingle RV, Hendey QB (1984) Late Mesozoic and Tertiary sediment supply to the Easter Cape Basin (SE Atlantic) and palaeo-drainage systems in southwestern Africa. Mar Geol 56:13-26

Droz L, Mougenot D (1987) Mozambique upper fan: origin of depositional units. AAPG Bull 71:1355-1365

Emmel B, Kumar R, Ueda K, Jacobs J, Daszinnies MC, Thomas RJ, Matola R (2011) Thermochronological history of an orogenpassive margin system: an example from northern Mozambique. Tectonics. doi:10.1029/2010TC002714

Figueiredo J, Hoorn C, van der Ven P, Soares E (2009) Late Miocene onset of the Amazon River and the Amazon deep-sea fan: Evidence from the Foz do Amazonas Basin. Geology 37:619622. doi:10.1130/G25567A.1

Flood RD, Manley PL, Kowsmann RO, Appi CJ, Pirmez C (1991) Seismic Facies and Late Quaternary Growth of Amazon Submarine Fan. In: Weimer P, Link MH (eds) Seismic facies and sedimentary processes of submarine fans and turbidite systems. Springer, New York, pp 415-433. doi:10.1007/978-1-4684-8276-8_23

Flores G (1973) The Cretaceous and Tertiary sedimentary basins of Mozambique and Zululand. Sediment Basins Afr Coasts 2:81-111

France-Lanord C, Spiess S, Adam K (2015) Neogene and late Paleogene record of Himalayan orogeny and climate: a transect across the Middle Bengal Fan, International Ocean Discovery Program Preliminary Report. International Ocean Discovery Program. doi:10.14379/iodp.pr.354.2015

Gallagher K, Brown R (1999) The Mesozoic denudation history of the Atlantic margins of southern Africa and southeast Brazil and the relationship to offshore sedimentation. Geol Soc London Spec Publ 153:41-53

Gorini C, Haq BU, dos Reis AT, Silva CG, Cruz A, Soares E, Grangeon D (2014) Late Neogene sequence stratigraphic evolution of the Foz do Amazonas Basin, Brazil. Terra Nov 26:179-185. doi:10.1111/ter.12083

Goudie AS (2005) The drainage of Africa since the Cretaceous. Geomorphology 67:437-456. doi:10.1016/j. geomorph.2004.11.008

Imran J, Parker G, Katopodes N (1998) A numerical model of channel inception on submarine fans. J Geophys Res 103:1219. doi:10.1029/97JC01721

Imran J, Parker G, Harff P (2002) Experiments on incipient channelization of submarine fans. J Hydraul Res 40:21-32. doi:10.1080/00221680209499870

INP (2014) Natural gas master plan.

Jokat W (2014) The expedition of the Research Vessel 'Sonne' to the Mozambique Basin in 2014 (SO230). Reports Polar Mar Res 676:126

Kolla V, Eittreim S, Sullivan L, Kostecki JA, Burckle LH (1980a) Current-controlled, abyssal microtopography and sedimentation in mozambique basin, southwest indian ocean*. Mar Geol 34:171-206

Kolla V, Kostecki JA, Henderson L, Hess L (1980b) Morphology and Quaternary sedimentation of the Mozambique Fan and environs, southwestern Indian Ocean. Sedimentology 27:357-378

Krishna KS, Ismaiel M, Srinivas K, Gopala Rao D, Mishra J, Saha D (2016) Sediment pathways and emergence of Himalayan source material in the Bay of Bengal. Curr Sci 110:363-372

Mahanjane ES (2012) A geotectonic history of the northern Mozambique Basin including the Beira High-A contribution for the understanding of its development. Mar Pet Geol 36:112. doi:10.1016/j.marpetgeo.2012.05.007

Mahanjane ES, Franke D, Lutz R, Winsemann J, Ehrhardt A, Berglar K, Reichert C (2014) MATURITY AND PETROLEUM SYSTEMS MODELLING IN THE OFFSHORE ZAMBEZI DELTA DEPRESSION AND ANGOCHE BASIN, NORTHERN MOZAMBIQUE. J Pet Geol 37:329-348. doi:10.1111/ jpg. 12589

Maslin MA, Christensen B (2007) Tectonics, orbital forcing, global climate change, and human evolution in Africa: introduction to the African paleoclimate special volume. J Hum Evol 53:443464. doi:10.1016/j.jhevol.2007.06.005

Milliman JD, Summerhayes CP, Barretto HT (1975) Quaternary Sedimentation on the Amazon Continental Margin: A Model. Geol Soc Am Bull 86:610. doi:10.1130/0016-7606(1975)86<610:QSOTAC >2.0.CO;2

Moore AE, Cotterill FPD, Broderick T, Plowes D (2009) Landscape evolution in Zimbabwe from the Permian to present, with implications for kimberlite prospecting. S Afr J Geol 112:65-88. doi:10.2113/gssajg.112.1.65

Mutti E, Normark WR, 1991. Seismic facies and sedimentary processes of submarine fans and turbidite systems, In: Weimer P, Link MH (eds), Springer, New York, pp. 75-106. doi:10.1007/978-1-4684-8276-8_4

Nairn AEM, Lerche I, Iliffe JE (1991) Geology, basin analysis, and hydrocarbon potential of Mozambique and the Mozambique Channel. Earth-Science Rev. 30:81-123. doi:10.1016/0012-8252(91)90014-7

Nelson CH, Escutia C, Damuth JE, Twichell DC, 2011. Interplay of mass-transport and turbidite-system deposits in different active tectonic and passive continental margin settings: external and local controlling factors. SEPM Spec Publ 39-66

Partridge TC, Maud RR (1987) Geomorphic evolution of souther Africa since the Mesozoic. S Afr J Geol 90:179-208

Reichert C (2007) Cruise Report: MoBaMaSis-BGR07.

Ridderinkhof H, De Ruijter WPM (2003) Moored current observations in the Mozambique Channel. Deep Res Part II Top Stud Oceanogr 50, 1933-1955. doi:10.1016/ S0967-0645(03)00041-9

Roberts GG, White N (2010) Estimating uplift rate histories from river profiles using African examples. J Geophys Res Solid Earth 115:1-24. doi:10.1029/2009JB006692

Rouby D, Bonnet S, Guillocheau F, Gallagher K, Robin C, Biancotto F, Dauteuil O, Braun J (2009) Sediment supply to the Orange sedimentary system over the last $150 \mathrm{My}$ : an evaluation from sedimentation/denudation balance. Mar Pet Geol 26:782-794. doi:10.1016/j.marpetgeo.2008.08.004

Said A, Moder C, Clark S, Ghorbal B (2015) Cretaceous-Cenozoic sedimentary budgets of the Southern Mozambique Basin: Implications for uplift history of the South African Plateau. J Afr Earth Sci 109:1-10. doi:10.1016/j.jafrearsci.2015.05.007

Salazar MU, Baker D, Malcolm F, Kornpihl D, Tekena W (2013) Frontier exploration offshore the Zambezi Delta, Mozambique. First Break 31:135-144 
Salman G, Abdula I (1995) Development of the Mozambique and Ruvuma sedimentary basins, offshore Mozambique. Sediment Geol 738:7-41

Schouten MW, De Ruijter WPM, Van Leeuwen PJ, Ridderinkhof H, (2003) Eddies and variability in the Mozambique Channel. Deep Res Part II Top Stud Oceanogr 50:1987-2003. doi:10.1016/ S0967-0645(03)00042-0

Schulz H, Lückge A, Emeis KC, Mackensen A (2011) Variability of Holocene to Late Pleistocene Zambezi riverine sedimentation at the upper continental slope off Mozambique, $15^{\circ}-21^{\circ} \mathrm{S}$. Mar Geol 286:21-34. doi:10.1016/j.margeo.2011.05.003

Stow DAV, Howell DG, Nelson CH (1985) Sedimentary, tectonic, and sea-level controls, In: Bouma $\mathrm{AH}$, Normark WR, Barnes NE (eds), Springer, New York, pp. 15-22. doi:10.1007/978-1-4612-5114-9_4

Tinker J, de Wit M, Brown R (2008) Linking source and sink: Evaluating the balance between onshore erosion and offshore sediment accumulation since Gondwana break-up, South Africa. Tectonophysics 455:94-103. doi:10.1016/j.tecto.2007.11.040

Van der Lubbe JHJL, Tjallingii R, Prins MA, Brummer, G.J.A., Jung, S.J.A., Kroon D, Schneider RR (2014) Sedimentation patterns off the Zambezi River over the last 20,000 years. Mar Geol 355:189-201. doi:10.1016/j.margeo.2014.05.012

Walford H, White N, Sydow J (2005) Solid sediment load history of the Zambezi Delta. Earth Planet Sci Lett 238:49-63. doi:10.1016/j.eps1.2005.07.014
Weatherall P, Marks KM, Jakobsson M, Schmitt T, Tani S, Arndt JE, Rovere M, Chayes D, Ferrini V, Wigley R (2015) A new digital bathymetric model of the world's oceans. Earth Sp Sci 2:331345. doi:10.1002/2015EA000107

Weimer P, Link MH, 1991. Seismic facies and sedimentary processes of submarine fans and turbidite systems, In: Weimer P, Link MH (eds), Springer, New York, pp. 3-7. doi:10.1007/978-1-4684-8276-8_1

Wessel P, Smith, W.H.F., Scharroo R, Luis J, Wobbe F (2013) Generic mapping tools: Improved version released. Eos Trans Am Geophys Union 94:409-410. doi:10.1002/2013EO450001

Wildman M, Brown R, Beucher R, Persano C, Stuart F, Gallagher K, Schwanethal J, Carter A (2016) The chronology and tectonic style of landscape evolution along the elevated Atlantic continental margin of South Africa resolved by joint apatite fission track and (U-Th-Sm)/He thermochronology. Tectonics 35:511-545. doi:10.1002/2015TC004042

Wiles E, Green A, Watkeys M, Jokat W, Krocker R (2014) A new pathway for Deep water exchange between the Natal Valley and Mozambique Basin? Geo-Marine Lett 34:525-540. doi:10.1007/ s00367-014-0383-1

Wiles E, Green A, Watkeys M, Jokat W (2017) Zambezi continental margin: Compartmentalized sediment transfer routes to the abyssal Mozambique Channel. Mar Geophys Res. doi:10.1007/ s11001-016-9301-4 